UDC 631.4(094)

\title{
Development on the basis of vegetable oils and seeds of olive crops of products for feed of sportsmen
}

Belinska A. ${ }^{1}$, Matveeva T. ${ }^{2}$, Papchenko V. ${ }^{3}$, Bochkarev S. ${ }^{4}$

${ }^{1-3}$ Ukrainian research institute of oils and fats of NAAS, Dziuba avenue, 2A, Kharkiv, 61019, Ukraine, ${ }^{4}$ National technical university "Kharkiv polytechnic institute», Bagaleya Str., 21, Kharkiv, 61020, Ukraine; e-mail: 1'belinskaja.a.p@gmail.com, ${ }^{2}$ matveeva7390@gmail.com, ${ }^{3}$ vikucya@gmail.com, ${ }^{4}$ bochkarev.s.v@gmail.com

The purpose. Substantiation and development of protein-fatty basis for sacchariferous confectionery products with the increased biological value, downgraded caloricity and extended shelf life which can be used for organization of balanced diet for sportsmen. Methods. Organoleptic and physicochemical parameters of protein-fatty basis, fat content in olive seeds are determined by means of standard techniques; amino acid composition - by ISO 13903:2005; oxidative stability — by rapid method of «active oxygen» at temperature $85 \pm 1^{\circ} \mathrm{C}$ at easy approach of light and air in reactor of barbotage type with constant feed rate of air and mixing; period of induction is determined graphically on curves of change of peroxide value. To design experiments and process data they applied mathematical methods with the use of software packages Microsoft Excel and Statistica. For calculation of ratio of ingredients in protein-fatty basis they used Sheffe simplex-trellised plan. Results. Sampling of ingredients of protein-fatty basis is proved. The volumetric part of olive seeds is counted which matches to ratio 2:1:1 on essential amino acids leucine:isoleucine:valine. Calculation of the optimum content of olive seeds in protein-fatty basis with the purpose of delay of oxidation processes is carried out: seeds of sunflower $-20 \pm 5 \%$ vol., flux $-50 \pm 5$, sesame $-30 \pm 5 \%$ vol. Conclusions. Sampling and content of ingredients is substantiated of protein-fatty basis balanced on essential amino acids with branched circuit (leucine, isoleucine, and valine) and tryptophan, and also irreplaceable polynonsaturated fatty acids. The developed protein-fatty basis is used in structure of sacchariferous confectionery products that promotes raise of biological value, decrease of caloricity and raise of oxidative stability last.

Key words: feed of sportsmen, vegetable oils, olive seeds, essential amino acids, polynon-saturated fatty acids.

https://doi.org/10.31073/agrovisnyk201811-24

State of the art. Soil resources are the basis for the development of the agrarian sector of the country's economy and the provision of an environment favorable to human beings. Due to the quality of soil resources, our country occupies one of the leading places in the world, since about $60 \%$ of the arable land is occupied by chernozem soils.

Unfortunately, the system of soil resources management in the last quarter of the century in Ukraine is not balanced enough and does not ensure the maintenance of a good state of the soil to the proper extent. One third of the arable land area of Ukraine is eroded, about $40 \%$ is over-densified and $20 \%$ has unregulated acidity, almost $70 \%$ of arable land is constantly experiencing a shortage of moisture available to plants, and the deficit of nutrients remains.

Because of this, part of the country's soil resources is in pre-crisis, and sometimes in a crisis situation with a tendency to deteriorate. Due to the insufficient consideration of the soil cover characteristics in agricultural production, the genetic potential of modern varieties and hybrids is not fully realized, and the efficiency of introducing new tillage technologies, fertilization, irrigation, etc. is reduced.

In 2015, the current land legislation was amended in order to simplify business conditions, in particular, the rule that the use of agricultural land should be carried out in accordance with land management projects that ensure the ecological and economic justification of crop rotation and the regulation of the land is excluded from the Land Code of Ukraine, and the provisions of the Law of Ukraine "On Land Protection" were deleted as to the necessity of approving the norms of the optimal ratio of crops in crop rotations in various natural-agricultural areas [1].

These steps have indeed led to an increase in the profitability of crop production, but also stimulated land users to introduce soil-fueled crop rotation instead of soil-protecting, which is less profitable. The discrepancy between the use of soil resources in Ukraine for the requirements of rational nature management is a direct 
consequence of the contradiction between the national interests of preserving the soil and private interests by obtaining a quick return on agricultural activity and directly related to the uncontrolled use of arable land on the rental rights.

Thus, due to the increasing degradation of soils in the context of the gradual attraction of land in commoditymoney relations, the task of improving the system of management of soil resources in the country on the new organizational and methodical basis comes to the fore.

Reorganization of soil protection system in Ukraine. In order to increase the effectiveness of state control over the use and protection of land, the National Academy of Agrarian Sciences of Ukraine and NSC ISSAR repeatedly raised the issue of establishing the Soil Protection Service in our country [2-3].

After all, reformed from the State Land Inspection, such a state institution starts work in the system of the State Service of Ukraine for Geodesy, Cartography and Cadastre [4]. However, first of all, state inspectors in the field of state control over the use and protection of land are tracing issues of unauthorized occupation of land, unplanned use of land and removal of the fertile soil layer, and the issue of deterioration of soil fertility and degradation is still of secondary importance [5].

On the other hand, financing of soil protection measures from the state budget in recent years in the framework of state programs has been discontinued and these functions are actually transferred to local authorities. According to the results of the state audit in early 2018, the Accounting Chamber of Ukraine determined that from UAH 773 million of targeted funds received on local government accounts in the order of compensation for losses of agricultural and forestry production, only $7.9 \%$ were used for land conservation measures, and $11.8 \%$ were in general at deposit accounts in banks [6]. These facts clearly indicate extremely inefficient management of the protection and use of land and soils, when government structures have obligations, but do not have the funds, and local authorities, on the contrary.

In the current situation, the scientific support of the reorganization of the soil protection system in Ukraine by NAAS scientific institutions is, first of all, in developing a set of necessary regulatory and normative and methodological documents. An effective toolkit is needed for effective management.

NSC ISSAR, together with the State Committee on Soil Protection, prepared a draft Resolution of the Cabinet of Ministers "On the Norms of the Quality State of Soils", which should regulate the issues of boundary changes in soil quality indicators under the influence of economic activity.

The further improvement of the organizational principles of the soil protection system in Ukraine is largely due to the implementation of the National Plan of Action for Combating Land Degradation and Desertification, approved by the Cabinet of Ministers of Ukraine Decree No. 271-r of March 30, 2016, which is aimed at fulfilling Ukraine's obligations within the framework of the UN Convention to Combat Desertification, ratified by the Verkhovna Rada of Ukraine on July 4, 2002 (No. 61-IV).

By the Resolution of the Cabinet of Ministers of Ukraine of January 18, 2017, a Coordinating Council on the Issues of Combating Land Degradation and Desertification was set up, at its first meeting was on May 4, 2018, 3 main voluntary national tasks were adopted to achieve a neutral level of land degradation.

In particular, the first of these tasks is to achieve a stable level of organic carbon content in agricultural soils by 2020 , and to increase it by no less than $0.1 \%$ by 2030 , including by the zones: Polissya - by $0,10-0,16 \%$; Forest Steppe and Steppe - by $0.08-0.10 \%$. Consequently, the maintenance of humus content in the soil nowadays is not only a matter for farmers but a national commitment to the international community.

Actualization of soil information. The main prerequisite for the sustainable management of Ukrainian soil resources is to receive up-to-date and objective information about their quality status. Unfortunately, the data available today are outdated and only partially true, because over 50 years after the completion of large-scale surveys between 1957 and 1961, the soil cover has undergone significant changes.

In this regard, the actual state of soil resources can be estimated only if a complex soil survey is carried out, or a combination of a refinement survey with a well-established soil monitoring system. The requirements for soil information in connection with European integration of Ukraine are increasing, which requires harmonization of the diagnostics, classification and mapping of soils. 
The first map integrated with the international methodology was the National Map of Organic Carbon Content in the Arable Layer of Soils of Ukraine, developed in 2017 by order and according to the FAO methodology. The map contains information on carbon content $(\%)$ in a layer $0-30 \mathrm{~cm}$, density $\left(\mathrm{g} / \mathrm{cm}^{3}\right)$ and carbon stock in soil (t/ha) with a spatial resolution of $1 \mathrm{~km}$.

NSC ISSAR developed scientific and methodical approaches to conducting a second large-scale survey; maps of the resource potential of the Steppe, Forest-steppe and Polissya zones were created for the main agricultural crops, which allow to evaluate objectively agro-investment attractiveness of the land, their resource capabilities and directions for improving the specialization of agriculture. At present, the task is to develop a national classification of soils, taking into account the results of the classification of soils of the FAO and the world reference base (the WRB).

The necessity of conducting complex soil surveys in 2016-2020 is foreseen by the aforementioned National Plan of Action for Combating Degradation and Desertification, and on the lands of experimental farms of NAAS, according to the decision of the NAAS General Assembly from April 18, 2018, a gradual renewal of soil maps is envisaged.

At present, in accordance with the Decree of the Cabinet of Ministers of Ukraine dated October 17, 2012 No.1051 "On Approval of the Procedure for the State Land Cadastre", large-scale ground surveys are conducted aimed at specifying nomenclature names, properties and mapping of agro-industrial groups of land plots for their further normative monetary valuation of land.

Management of soil information. In Ukraine, there is one of the main sources of information on the state of soil cover - soil monitoring, which is conducted in accordance with the Decree of the Cabinet of Ministers of Ukraine "On Approval of the Regulation on Land Monitoring" dated August 20, 1993 No. 661, "On Approval of the Regulation on the State Environmental Monitoring System" from March 30, 1998 No. 391 and the Order of the Ministry of Agrarian Policy of Ukraine "On Approval of the Regulation on the Monitoring of Soils on Agricultural Land" of February 26, 2004, No. 51.

However, due to the departmental dispersal of monitoring of the state of land in Ukraine and its methodological inconsistency, the information obtained is in separate, unstructured databases, and, moreover, mainly on paper. Such a state does not allow us to fully utilize the arrays of information, evaluate and predict the state of the soil resources.

According to the Strategy of the Information Society Development in Ukraine, Ukraine's full-scale accession to the global information space, accelerated development of the information sector of the economy, and the provision of free access to information and knowledge are the main tasks of the development of the information society in Ukraine [7].

At the fifth FAO Plenary Meeting of Global Soil Partnership, which was held on June 20-22, 2017, a new international initiative to create a Global Soil Information System was approved. Currently, in 117 countries, organizations and institutions responsible for the creation of a national soil information network and the harmonization of soil information with an international database are identified.

In Ukraine, the NSC ISSAR is the basic institution for the organization of the National Soil Information Center. In the future, the implementation plan for the creation of a Global Soil Information System in 2016-2020 includes the following main tasks for the participating countries, including for Ukraine:

- development and coordination of the Code of Ethics and its copyright policy in the exchange and use of soil information;

- formation of the Ukrainian web-platform and templates for collecting soil profiles and accompanying analytical data for soil cuts;

- harmonization with international requirements, maintenance and replenishment of the national computer database of soil profiles, definition of a set of coordinated "reference" profiles of soils of Ukraine;

- the creation of digital national maps of soils of different scales, based on the international methodology of digital terrestrial mapping (eSOTER) and their coordination with neighboring countries;

- Harmonization of the national database "Properties of Soils of Ukraine" with the technical requirements of the Harmonized World Soil Database (HWSD); 
- creation and maintenance of a national information soil portal with products and services on the basis of spatial infrastructure of soil data;

- development and implementation of a training program for a new generation of specialists in the field of digital mapping, monitoring and forecasting of soil condition.

The importance of preservation and harmonization of soil information is due to its value, since obtaining a complete set of data on a single soil cut is worth around $\$ 1,000$. Currently, in the framework of the 1 task of NAAS "Soil Resources: Development Forecast, Balanced Use and Management", the following necessary attributes of soil and information support, such as modern soil mapping techniques, have been developed in 2016-2020 with the use of a set of terrestrial and remote survey methods, a large number of thematic cartograms and databases, work is under way to create a unified information system for field stationary experiments and methodological approaches to the creation of the National Soil Informational system of Ukraine.

Taking into account qualitative features of soils (properties, regimes, bonitetes, investment attractiveness) on the modern geoinformation basis enables to gradually move to sustainable land use, which corresponds to the soil properties and local soil-climatic conditions.

Technological provision of management of soil resources. During the last decades, the agrarian complex of Ukraine suffered from a shortage of resources for high-tech economy management, which was particularly affected by measures to restore soil fertility and prevent degradation.

If energy-consuming soil conservation technologies developed at the time of the USSR were introduced now, this will have a negative impact on the cost of current agricultural products and their competitiveness, although it will have a positive effect in the future. The implementation of the new strategy for the management of soil resources envisages the rejection of outdated approaches to the reclamation of saline, alkaline, acidified, leached and other soils with unfavorable agronomic properties in favor of adaptive-landscape spatiallydifferentiated technologies. In addition, the sustainable development of the agrosphere involves preserving biodiversity and biological quality of the soil, harmonizing the productive and ecological functions of soils, balancing water flows in the landscapes, requiring new technological support with the maximum use of natural mechanisms of self-regulation of the soil body.

On eroded lands, it is important to ensure the introduction of technologies for the design of agricultural land management, which minimizes the risk of developing erosion processes. In particular, the use of the basin approach provides for the clarity and ease of allocation of boundaries, a hierarchical structure that allows for the consideration of the spatial distribution of soil cover and geosystemic interconnections and allows for the implementation of all types of environmental monitoring using geoinformation models.

An important component of sustainable management of soil resources is the improvement of agrochemical support on the principles of managed agriculture, rational fertilizer systems and their maximum adaptation to soil-climatic conditions. Computerized fertilizer management systems and methods for operative diagnostics of mineral nutrition of plants help to increase return on costs.

Balancing humus on a relatively satisfactory level is possible in the case of involving in the process of production of agricultural products all raw materials of organic origin: waste of animal, poultry, plant growing, communal services and processing industry.

The diversity and specificity of this raw material requires the development and introduction of new technologies for the production and use of fertilizers on its basis, which are aimed at increasing the productivity of crop rotation with the reproduction of soil organic matter. The management of the waste depends on solving the whole ecological and resource situation in Ukraine, since, on the one hand, waste is the main factor of environmental pollution, and on the other hand, it has a "frozen" certain part of the resource and energy potential.

Financial support. It should be borne in mind that no matter what progressive and competent land users, without the help of the state, they will not be able to provide high-tech reproduction of soil fertility. In accordance with the policy of decentralization and increase of funds in rural communities, it is necessary that at least a small 
part of them are spent on solving local soil protection problems: cleaning small rivers and forest belts, repairing anti-erosion facilities, purchasing perennial herbs for inoculation of slopes, etc.

Unlike Ukrainian experience, European farmers have long been receiving state subsidies for promoting environmental services, including conservation of soil and biodiversity [8]. However, the limited budget and the lack of adaptation of subsidies to local environmental, economic and cultural conditions did not allow for a neutral level of land degradation. In this regard, the EU's new agrarian policy for 2014-2020 will further link direct payments to farmers with the requirements of maintaining land in a good agricultural and ecological state [9].

In the process of approximation of national legislation to the EU legislation, it is important to avoid unwarranted copying and to take into account national interests and specifics of our country as much as possible. However, one cannot ignore the valuable experience of different countries in the management of soil resources.

Harmonization processes in land are constantly taking place in the EU countries as well. For example, each country has supplemented the list of monitoring sites of the European network according to the degradation processes that prevail in its territory: Estonia - on peatlands and re-compacted soils, Poland - on erosionhazardous, reclosed and contaminated soils, Italy and Germany - on erosion- hazardous, re-compacted soils, and in areas of high population density and livestock concentration [10].

NSC ISSAR developed a draft of National Program for the Use and Protection of Soil Resources of Ukraine, adapted to present-day realities in the light of international experience [11]. It is suggested that some of the necessary measures can be carried out at the expense of the land users themselves, since they have a quick self-sufficiency of costs through increased crop yields, the rest of the measures involve financial support from the state or local budgets.

Thus, at the expense of the state budget, construction and reconstruction of anti-erosion hydrotechnical and anti-landslide structures, creation of new protective forest stands, soil monitoring and agrochemical certification of agricultural lands, functioning of the national soil information system and economic stimulation of the achievement of the extended fertility reproduction of soils should be carried out.

At the expense of partial financing from the state or local budgets, chemical soil reclamation, extraction and introduction of peat and sapropel, seed crops can be carried out. At the expense of the landowners and land users, part or all of the cropping works, anti-erosion agrotechnical measures, the introduction of degraded and unproductive arable land, improvement of the condition of the hayfields and pastures could be carried out.

\section{Conclusions}

The problem of conservation of soil resources and the prevention of soil degradation in Ukraine requires new methodological approaches and a comprehensive solution in the organizational, informational, technological and financial areas. At present, the complexity and co-ordination of actions are achieved within the framework of the implementation of the National Plan of Action on combating land degradation and desertification, but the next step should be the adoption of the National Program for the Use and Protection of the Soil Resources of Ukraine.

\section{References}

1. Zakon Ukrainy «Pro vnesennia zmin do deiakykh zakonodavchykh aktiv Ukrainy shchodo sproshchennia umov vedennia biznesu (derehuliatsiia)». [Law of Ukraine "On Amendments to Certain Legislative Acts of Ukraine on Facilitation of Business Conditions (Deregulation)"]. Vidomosti Verkhovnoi Rady. 2015. No 21. P. 133. [In Ukrainian].

2. Baliuk S.A., Medvediev V.V., Miroshnychenko M.M. (2009). Upravlinniu gruntovo-zemelnymy resursamy - derzhavnu pidtrymku. [Management of soil and land resources - state support]. Visnyk ahrarnoi nauky. No 4. P. 10-12. [In Ukrainian]. 
3. Zubets M.V., Medvediev V.V., Baliuk S.A. (2011). Stratehiia zbalansovanoho vykorystannia i okhorony zemel Ukrainy. [Strategy of balanced use and protection of lands of Ukraine]. Visnyk ahrarnoi nauky. No 4. P. 19 - 23. [In Ukrainian].

4. Postanova Kabinetu Ministriv Ukrainy vid 22 lypnia 2016 r. No 482 «Pro vnesennia zmin do deiakykh postanov Kabinetu Ministriv Ukrainy». [The Resolution of the Cabinet of Ministers of Ukraine dated July 22, 2016 No. 482 "On Amendments to certain Resolutions of the Cabinet of Ministers of Ukraine"]. [In Ukrainian].

5. Zvit pro pidsumky roboty Holovnoho upravlinnia Derzhheokadastru u Kharkivskii oblasti za 2017 rik. [Report on the results of the work of the Main Directorate of the State Geocodistry in the Kharkiv region for 2017]. 30 p. URL: http://kharkivska.land.gov. ua/info/zvity-pro-pidsumky-diialnosti-holovnohoupravlinnia/ [In Ukrainian].

6. Zvit pro rezultaty audytu efektyvnosti vykorystannia koshtiv derzhavnoho biudzhetu, spriamovanykh na upravlinnia u sferi vykorystannia ta okhorony zemel silskohospodarskoho pryznachennia derzhavnoi vlasnosti, ta rozporiadzhennia nymy. Zatv. rishenniam Rakhunkovoi palaty Ukrainy vid 06.03.2018 r. Rakhunkova palata Ukrainy. [Report on the results of the audit of the effectiveness of the use of state budget funds aimed at managing and managing the use and protection of agricultural land of state ownership. Shuttle by the decision of the Accounting Chamber of Ukraine dated March 6, 2018, the Accounting Chamber of Ukraine]. 2018. $54 \mathrm{p}$. [In Ukrainian].

7. Rozporiadzhennia Kabinetu Ministriv Ukrainy vid 15.03.2013 No 386-r «Pro skhvalennia Stratehii rozvytku informatsiinoho suspilstva v Ukraini». [Order of the Cabinet of Ministers of Ukraine dated March 15, 2013 No 386-r "On Approval of the Strategy of the Information Society Development in Ukraine"]. [In Ukrainian].

8. Schomers S., Matzdorf B. (2013). Payments for ecosystem services: A review and comparison of developing and industrialized countries. Ecosystem Services. 2013. V. 6. P. 16 - 30. doi.org/10.1016/j.ecoser.2013.01.002.

9. Huack J., Schleyer C., Winkler K.J., Maes J. (2014). Shades of Greening: Reviewing the Impact of the new EU Agricultural Policy on Ecosystem Services. Change and Adaption in Socio-Ecological Systems. V. 1. P. 51 - 62. doi: 10.2478/cass-2014-0006.

10. Morvan X., Saby N.P., Arrouays D. et al. (2008). Soil monitoring in Europe: A review of existing systems and requirements for harmonisation. Science of Total Environment. V. 391(1). P. 1 - 12. doi: 10.1016/j.scitotenv.2007.10.046

11. Zaryshniak A.S., Pylypenko L.A., Dyshliuk V.le. et al. (Baliuk S.A., Medvediev V.V., Miroshnychenko M.M. Eds.) (2015). Natsionalna prohrama okhorony gruntiv Ukrainy. [National Program of Soil Protection of Ukraine]. Kharkiv: TOV «Smuhasta typohrafiia». 59 p. [In Ukrainian]. 